\title{
Discourses on Hamlet's Journey in Turkey
}

\section{Hilal Erkazanci Durmus Hacettepe University}

\section{Introduction}

The retranslation of a literary text is in effect "not only the translation of a text which is already translated, yet a way of thinking about translation" (Samoyault 233). ${ }^{1}$ Therefore, emphasis on dialogic intertextual relationships that any post-translation rewriting may establish with the rather complex web of texts can ultimately yield more productive and creative ways of thinking about retranslation. The term post-translation studies was coined by Siri Nergaard and Stephano Arduini and was later more fully developed by Edwin Gentzler as a way of demonstrating how source texts transform into new and unique images within the minds of those people recontextualizing the texts for other cultures and languages. For the sake of clarity in this investigation, it might be fruitful to briefly review the notions of rewriting, post-translation rewriting, and retranslation.

To start, rewriting refers to any discursive activity, including translation, anthologizing, editing and so forth, which ultimately contributes to the construction of an "image" of the source text (Bassnett and Lefevere 10). ${ }^{2}$ Following Bassnett and Lefevere, who believe that in today's global world, a text's image is in effect more influential than the written text itself (9-10), Gentzler calls for a post-translational turn in translation studies which concentrates on the image created by the rewriters who have played with source texts and remoulded them into their own novel images rather than the image that was created by the source text or even by the paratextual and/or extratextual materials regarding the source text (199). ${ }^{3}$ In this context, the social narrative theory framework encourages the researcher to consider the text more deeply, reading between the lines so to speak, and as a result, looking beyond the text that is presented, and to consider the text within the greater social and cultural framework. As Mona Baker suggests, "every story is a narrative and every experience is a narrative experience" (17). ${ }^{4}$ Hence, every time a source text is rendered into new image(s), the narratives embedded in the text become reframed in elusive or radical ways. ${ }^{5}$ Therefore, the reframing of source texts can serve a significant role in the exploration of rewriters'

\footnotetext{
1 Translations of all quotations are mine unless otherwise stated.

2 Throughout the present study, the notion of image refers to the projection of a source text in a given society within the context of rewriting; however, when used in the context of imagology, the notion refers to "the mental silhouette of the other, who appears to be determined by the characteristics of family, group, tribe, people or race" (Beller 4).

3 The notion of paratext refers to peritextual elements within a text and/or epitextual elements outside a text which serve an introductory and presentational role to shape the reader's approach to the text (Genette 3), whereas extratext which refers, in the words of Tahir-Gürçağlar (Politics and Poetics 203), to "the general meta-discourse" about a text does not necessarily have to play a role in the reception of a text.

${ }^{4}$ Narratives are classified into four categories: personal, public, conceptual, and meta-narratives (for a detailed discussion of narratives, see Somers and Gibson).

${ }^{5}$ Framing is a methodological tool of narrative theory that serves to construct the way a narrative is presented to the receiving culture. Narratives can be presented through temporal and spatial framing, selective appropriation of textual material, paratextual framing, and through the use of visual elements such as colour and image (Baker 105-141).
} 
embeddedness within particular narratives and can ultimately aid them in maintaining and elaborating as well as contesting and challenging the source text's narrative.

In addition, following Jean Baudrillard, Gentzler points out that source texts "do not simply originate, but rather circulate, moving internationally and intersemiotically into new media and forms" (ii). As a result, (re)translations might actually be less pertinent in the variety of multi-media versions they are presented in, such as, film, theatre, musicals, video games, and so forth, than the images that have been created to represent the source text within a receiving culture. Worthy of note here is the study by Inez Okulska, who focuses on particular cases where interlingual translation acts as an impulse that incites numerous "transmedial derivatives" which were based on differing cases of post-translation rewriting that in their own way reinterpret and reorient the source text's image (58). In this sense, post-translation rewriting appears to be more related to "thinking less in terms of [re]translating words" and more with the rendering of an image that can be presented to illuminate if not incite the reader (Gentzler 134). Hence, the emphasis of the posttranslational turn on the "speaking-after" rather than the "carrying across" dimension of translation, to use Gentzler's words (226), would expand retranslation studies into a wider spectrum and into an age of new technologies.

Against the backdrop of these aforementioned points, the impetus for choosing Hamlet (1992) for the present study is threefold: First, as Gentzler notes within the Chinese context, Hamlet, a freely adaptable work in transmedial rewriting, constitutes fertile ground to examine numerous ways through which texts reread and rewrite each other. Second, Hamlet is significant in the Turkish literary system by virtue of its historical position (as a symbol of Turkey's western and modern image), as testified by the numerous versions that have been translated and rewritten in Turkish. Third, a post-translation analysis would be fruitful because the cinematic and various theatrical versions of Hamlet produced in Turkey provide key and distinctive images (e.g., classical Turkish songs, Kurdish songs, Atatürk's address to Turkish youth, political party slogans, Islamists in green jackets, the headscarf, an Ottoman palace, a nargile, Hamlet in a parka and combat boots, Hamlet as a powerful Turkish woman, and so forth) which are meant to stimulate the Turkish audience's imagination as well as enable them to better participate within the imaginative process of the collective Turkish identity in a variety of ways and over differing periods of time.

Therefore, the focus of this analysis will be on how various extratextual discourses frame the retranslations and post-translation rewritings of Hamlet within the Turkish cultural milieu (e.g., what narratives frame the Turkish versions and how they differ from or concur regarding such framing). In doing so, also being explored is why particular renderings of this dramatic play ultimately sparked discourse, which played a significant role in the (trans) formation of Turkey's self-image(s). This analysis thus benefits from imagology in an aim "to understand a discourse of [national] representation" (Leerssen 27). Ultimately, the focus will be on how the implications of various extratextual discourses affected the expansion of the boundaries of retranslation studies (e.g., how multiple artistic and creative works born out of prototypical interlingual translation are approached as well as how the post-translation effects of Hamlet are discussed in Turkey).

\section{Hamlet in Turkey}

The universal themes that can be found throughout William Shakespeare's dramatic work Hamlet (e.g., revenge, love, power struggles, and family tragedy) have enabled this famous work of English 
dramatic literature to easily penetrate the realms of Turkish literature and cinema. The translation of Hamlet has been a strategic means in the pursuit of the transformation of Turkish society and culture in line with westernization and modernization movements. Among the various versions of Hamlet in Turkey, the translations that fall under the domain of translation proper remain faithful in their attempt to recreate the play's storyline as well as maintain the aesthetic and historical resonances of the source text. However, various Turkish rewritings for both stage production and also cinematic appropriation reveal how a literary text can flourish in its own unique way beyond the printed page.

As Kathryn Grossman points out, a literary text can be subject to a metamorphosis in certain cases where it is transposed into a different medium and in doing so it can be "tailored to local values, tastes, and interests by inflecting it with distinct cultural flavours" (49). As a result of the varying approaches that can be taken with a literary text, it is necessary to compare different versions of a literary text "in ways that extend beyond the sole criterion of fidelity to the text" (Grossman 491), and as a result, it is possible to explore three unique interconnections between a literary text and its redactions and transformations: (i) representation (mimesis) which clings to the source text by observing fidelity to its storyline and characters (Grossman 488), (ii) extrapolation which "permits creative enterprises only loosely connected to the text" and uses one of its characters who "is plucked from his or her literary context and placed in a new situation [...]", and (iii) commodification which is based on a commercial use of the character(s) and/or cultural attributes of the source text (Grossman 489).

Since Hamlet has been acknowledged in the Turkish literary system as a prestigious and canonical work of western literature, its status has required some level of fidelity from translators. This is important because Hamlet has had significant influence on the Turkish literary system, inspiring a plethora of dramatic texts and stage productions. At this point, it is necessary to focus on the notion of "re-memberment", which Julie Tarif utilized in association with both human memory and the body as a way of demonstrating how retranslation can remind readers of "the literary legacy" of the source culture by ensuring the survival of the source text within the memory of the receiving culture as well as how the retranslation of a literary text can mould the latter's literary system by stimulating further translations and even further original writings (38). Furthermore, as Tarif points out, whereas the representation of a literary work is aligned with "rememberment", its extrapolation and commodification tie in with this idea of "dis-memberment" (40). As will be seen in the following discussion, Hamlet has been re-membered through a variety of retranslations that both preserve the source text's style and respect its quasi-sacred status, yet Hamlet has also been dis-membered through a variety of other post-translation rewritings that have in some way or another appropriated the source text to more fully align with the local socio-political circumstances of the time and/or situation.

These circumstances can be recognized within even the first translation of Hamlet into Ottoman Turkish that was carried out by Mehmed Nâdir in 1881. Since the Ottoman Sultan at the time, Abdülhamid II, prohibited the performance of Shakespeare's tragedies that included any form of political theme (e.g., power struggle, rebellion, injustice, and so forth) because these works were viewed as a potential threat to the monarchical reign (Paker 91), Mehmed Nâdir only translated the first act along with a few pages of the second act of the dramatic play in which the king was not seen being murdered (Şengel 1). The partial translation by Mehmed Nâdir, which was published in 
Harine-i Evrak, the first Ottoman scientific and literary journal, was followed by Abdullah Cevdet's full translation which was published in 1908 following the declaration of a constitutional monarchy in the Ottoman Empire. Abdullah Cevdet, who was an opponent of monarchy, was an ardent supporter of modernization and westernization, and as a result, he created his version of Hamlet for "an educated readership, in its adherence to the norms of heavily Persianized poetic diction, current in his time" (Paker 94). Being a word for word translation which sought to reflect Shakespeare's poetic language, Abdullah Cevdet's rendering was difficult to comprehend by a majority of uneducated readers for whom the Persianized and Arabicized Ottoman literary style tended to be alienating (Paker 94). Naturally, at first glance it may seem contradictory to ascribe a modernizing role to a translation that maintained stylistic and discursive characteristics of an old literary system which only an elite group could appreciate (Paker 92); however, a second glance reveals that it was a significant step towards modernization of the Turkish literary system in general, and in particular the Turkish theatre, to produce a dramatic translation which attained what could be "considerable adequacy" (Paker 92).

After the proclamation of the Turkish Republic, Abdullah Cevdet retranslated Hamlet in line with the plain language movement that was initiated in the late $19^{\text {th }}$ century, acknowledging that his previous grandiloquent style had caused some level of inconvenience even for the educated readership (Cevdet, Hamlet'in Tablili 5511). Interestingly, the Ministry of Education chose to publish Kamuran Şerif Saru's translation in 1927. Saru's rendering was a summarized version published as part of the series titled Examples from the World Literature which had been commissioned for educational purposes. In that same year, Muhsin Ertuğrul, the founder of what has become known as modern Turkish theatre, produced a new Turkish Hamlet based on a performance-oriented Hamlet previously produced in German. His rendering differed from the past translations in that it prioritized stage production over poetic-language use (Paker 95).

Next, the year 1928 was monumental for the modernization of the Turkish language because this year ushered in the reform of the Turkish alphabet, which had been based on an Ottoman script alphabet and was now to be based on the adoption of the Latin-based alphabet, launched to create and educate a more western-oriented Turkish society. Years later in 1941 two professors from Istanbul University, Halide Edip Adivar, a republican activist, along with Vahid Turan, composed a translated version of Hamlet that was believed to better comply with the language reforms set forth by the new Turkish republic. Also, another academic in 1944, Professor Orhan Burian of Ankara University, retranslated Hamlet. Paker underlines that the 1941 and 1944 translations seemed to focus on "adequacy though both were entirely in prose, ostensibly for the reason that there was no equivalent of blank verse" found in Turkish literature (99). In terms of language purism, however, the 1944 translation utilized what can be considered a purer language. This is why Paker highlights that the 1944 version was perceived as a "more acceptable" translation (99). For instance, Burian translated the word "king" as "kiral", adding a "1" to the commonly used form of 'kral' (the Turkish word for king), which is highly likely an outcome of his objection of using foreign spellings.

Given that "during the 1940s, translations of certain classics were prepared with explanatory notes in order to be used in high schools" (Berk 8), it appears that the 1941 and 1944 translations include an unusually rich amount of peritextual elements. Adivar and Turan's translation includes a preface, a great many footnotes as well as a section dedicated to the author, along with a section 
for the historical context of the work and the characters. Likewise, Burian's translation includes a preface, footnotes as well as questions which were placed at the end of the translation in order to persuade the reader to more deeply inquire about his/her comprehension of each act within the Shakespearean drama.

Later, in 1965, came a translation by Sebahattin Eyüboğlu, who noted that he benefited not only from the Turkish translations of the previous retranslations, but also from the French translations of Yves Bonnefoy and Victor Hugo, admitting that his English skills were inadequate to translate the entire play (Eyüboğlu 3). Though Eyüboğlu's version seems to be an indirect translation, Paker points out that it can be characterized by "its free-flowing poetic prose, akin to free verse, which follows the lineation of the original, the diction being the same as that of contemporary Turkish poetry rooted in a simple and natural use of the language" (100).

As for Beklan Algan's 1970 adaptation, Hamlet 70, it was staged as a criticism of the degeneration of republican reforms that had taken place in Turkey. Algan recontextualized the source text to fit the social and cultural milieu of 1970s Turkey. In the Algan rewriting of Hamlet, the prince of Denmark was transposed into a realist and socialist republican younker who struggled to survive in his country. Algan used an epidiascope that displayed the protests from leftist activists' and workers' demonstrations as well as police arrests. His prologue transformed the soldiers from the play into the Turkish people themselves instead, who were to stand guard in front of Atatürk's bust, the Ghost speech into Atatürk's address to the Turkish youth, Rosencrantz and Guildenstern into American collaborators, Fortinbras into an imperialist, and Polonius into an oppressive police officer. Carrying revolutionary books and wearing a parka and combat boots, which were once viewed as the political symbols of left-wing groups, Hamlet battled against the imperialist powers and right-wing groups within Turkey.

Metin Erksan's 1976 film adaptation Intikam Meleği: Kadmn Hamlet [The Angel of Vengeance: Lady Hamlet] depicts Hamlet as a modern and powerful female character who graduated from theatre school in the United States. Suspicious about her father's accidental death, Hamlet returned to Turkey and vehemently denounced her mother's marriage with her uncle Kasim (Claudius), a voracious landowner. After she was informed by a ghost that her father had been murdered by Kasım, Hamlet sought revenge. Hamlet's friends Rezzan and Gül (Rosencrantz and Guildenstern) recommended she stage a play to alleviate her sorrow and together organized an improvizational theatre group. Staring at her uncle, Hamlet implied, during the play-within-a-play scene, that he had murdered her father in order to take possession of the father's wife and riches. Erksan's film adaptation of Hamlet frequently questioned important touchstone issues that affect society and politics, namely, wickedness and corruption.

In 1982 Professor Bülent Bozkurt of Hacettepe University composed a poetic prose translation of Hamlet which prioritized the idea of performability. As Bozkurt underscored in his preface, he did not seek to create a fluent translation that provided the reader with a smooth reading experience, nor was his intention to reshape the text to align with the current state of Turkish culture and language (Hamlet 19-21). Instead, his primary intention was to preserve Shakespeare's work "intact" and to abstain from "distorting" its textual properties (Hamlet 19). Bozkurt further pointed out that in his opinion some of the earlier renderings of Hamlet in Turkish created a deficient and misleading image of the Shakespearean text (Shakespeare'in Bütün Sözcükleri, 5). However, Bozkurt's views on the quasi-sacred status of Shakespeare's text were ultimately criticized 
by Neslihan Demirkol. According to Demirkol, Shakespeare's works are regarded by many academics and critics as static and unalterable literary texts; however, it is necessary to consider that theatre texts are instead dynamic texts that should be open to modification in order to be in line with the changing social and temporal conditions of any time period (7-8).

In Can Yücel's 1992 Hamlet version, Yücel positioned himself against the dominant ideology and literary canons of the time by creating a counter-discourse that allegedly fed upon "communism" and "obscenity" (Demirkol 55). Since Yücel composed a performance-oriented text, he did not hesitate to remove excerpts of the source text that he believed did not fit into his text's performability. Also worth noting is that Yücel did not see himself as a translator; he instead characterized himself as a teller in Turkish. Ironically, his adaptation included several words of Arabic and Persian origin, which from time to time appear to run the risk of alienating modern Turkish readers. Even though his version is imbued with allusions of modern Turkey's connection to its Ottoman roots (e.g., 'king' translated as 'padişah'), Yücel does ultimately contribute to the promotion of the source text's image by recreating a struggle against the dominant power, the opposition to royalty as well as the desire to write for and speak on behalf of common Turkish folks. Fatih Özgüven points out that Yücel's translation owes its success to the realization of the use of vulgar language intrinsic to Shakespeare's style (8). As a result, this appears to allow Yücel to abstain from both indemnifying Hamlet as well as consecrating its language (Demirkol 144).

With Müjdat Gezen's 1995 adaptation, Hamlet Efendi, the story is told of an improvizational theatre group comprised of Turkish and Armenian actors who stage a play at the time of the promulgation of the Turkish republic. Since their original play did not receive acclamation, one of the Armenian actors suggested staging Hamlet, which he believed would promote the modernization of the newly founded state. Gezen's version emphasizes that a shift from the traditional Turkish theatrical style to western theatrical forms is in harmony with the republican quest of westernization, and in doing so this adaptation went on to praise such republican reforms as the adoption of the Latin alphabet and western-style clothing.

Further retranslated versions of Hamlet proceeded; for example, Tolga Sağlam in 1999, Esen Genç in 2002 and Orhan Akıcı in 2004 as well as Müjdat Gezen, who produced a translation in 2000 by purportedly simplifying Burian's translation. ${ }^{6}$ Next, in 2004, Semih Çelenk produced Hamlet Renkli Türkese [Hamlet in Colour in Turkish], in which Hamlet's characters came together with the local characters (e.g., İbiş, a puppet theatre character, and Keloğlan, a fairytale character) from classic Turkish folktales and traditional Turkish theatre. Even though the main plot and dramatic structure of Hamlet were maintained in Çelenk's rewriting, particular Muslim practices were foregrounded (e.g., Gertrude's headscarf, non-alcoholic beverages, Islamic greetings, and so forth) in order to depict the prevailing socio-political landscape in Turkey at the time. Divergent symbols of political Islam such as the wearing of a green jacket, men having small and neatly trimmed moustaches, and use of some slogans from the ruling Justice and Development Party seemed to emphasize that Islam had become a major reference point within Turkish politics.

The Kurdish Hamlet, Cemil Toksöz's 2012 version, was produced by an Amsterdam-based theatre group RAST in cooperation with the Diyarbakir Metropolitan Municipal City Theatre. Based on dengbêj (storyteller), the Kurdish narrative art, Tokgöz's rewriting embellishes the 
western dramatical work with Anatolian and Middle Eastern folkloric features (e.g., Gertrude's headscarf, Claudius' nargile, Kurdish songs and customs). As Verstraete suggests, "the reimagining of the dengbêj culture through this Hamlet production could be seen as feeding the nostalgia for this [old] storytelling tradition in a time when even some of the actors had to (re)learn how to pronounce certain words" (65).

In addition, Hamlet was successively retranslated by various others such as Can Doğan in 2012, Vedii İlmen in 2013, Özdemir Nutku in 2013, Yeşim Misırc1 in 2014, Dilek Topal in 2017, Ahmet Gözler in 2017 and Seçil Akın in 2019. These successive retranslations of Hamlet over the years appear to point out, in Anthony Pym's words that, "a good index of public demand" continued for this work (79). The retranslations highlighted the above attempt to follow the more poetic prose style of the source text. It is necessary to note here that owing to these retranslations' close temporal proximity, one may disregard the need for updating any so-called ageing translation. Instead, one may consider that Turkish publishers wished only to invest in the repeated retranslation of Hamlet in order to capitalize upon its canonical status and as a result its marketability.

Also of note is Halit Erdem Oksaçan's 2017 version, which is presented in the book cover as a transliteration. Oksaçan's intralingual translation sought to introduce the modern Turkish reader to Abdullah Cevdet's Hamlet, which had become a symbol of opposition in the late Ottoman era. Since Cevdet's translation had coincided with the Constitutional Revolution, abolishing absolute monarchy, Oksaçan emphasized that it was necessary in this version to continue using the historical period's language, style, and discourse in order to introduce it to today's readership (qtd. in Uluşahin n.p.). Therefore, he did not pursue the simplification and/or purification strategies taken in a variety of previous retranslations; however, Oksaçan did include numerous footnotes in his translation, taking into consideration the alienating effect archaic words may have on modern Turkish readers who are less acquainted with the diction of the Ottoman era.

\section{Discourses on Turkish Hamlet}

This section focuses on how extratextual discourse portrays the various Turkish renderings of Hamlet to those in academia as well as the audience from the general public. Similarly to translators' and rewriters' active reframing of a source text, any extratextual material regarding a dramatic work can ultimately frame the translated version in a certain light and thus socialize the reading public into the wider narratives circulating in the receiving culture. As will be demonstrated, the discourse around the Turkish retranslations of Hamlet, including post-translation rewritings, are indicative of how Turkey's identity has been renegotiated over time to be in line with its shifting context and historicity.

Since Hamlet is a dramatic play driven by both social and political considerations, the reframing of this play through a variety of Turkish renderings is not free from its own political motivations. Saliha Paker underscores that the Turkish renderings of Hamlet tend to coincide with significant transitional periods that have taken place within Turkish culture and political history (89). The first translation, composed by Mehmed Nâdir three years after Sultan Abdülhamid II suspended the first ever constitution of the Ottoman Empire, has frequently been associated with the theme of censorship (see Şengel 1). In order not to offend the sensibilities of the reigning monarchical regime of the day, Nâdir was not able to translate the entirety of the dramatic work 
because of a scene involving the character of the king being killed as well as other scenes that presented various power struggles.

Hence, it is necessary to note here that the initial literary import of Hamlet into the Ottoman literary system has been framed within the broader narrative of Hamidian absolutism. For instance, Inci Enginün points out that various attempts to perform Hamlet were turned down by Abdülhamid II in his bid to root out any attempt which would debilitate the absolute monarchy (16). Along similar lines, Sevda Ayluçtarhan highlights that Abdullah Cevdet's 1908 translation of Hamlet was a "critical text" produced by a prominent culture-planner of the time in opposition to Abdülhamid II's absolutist regime (33). Ayluçtarhan further points out that Cevdet's Hamlet was motivated by his perception of the "parallels between Hamlet's step-father and Abdulhamid II, who had been brought to the throne (1876) on the condition that he would promulgate the Constitution (Kanun$i$ Esasi) but did not really keep his promise" (46).

Cevdet's translation was introduced to the Turkish audience at a time when the discourse of westernization was prevalent. The translation coincided with the announcement of a Constitutional Revolution that led to the dethronement of Abdülhamit II and ultimately to the promotion of western-inspired reforms. Since Cevdet was one of the ardent supporters of an Ottoman Renaissance through westernization, his translation has been framed as a symbol of the western canon within the Turkish context. For instance, Demirkol regards Cevdet's translation as an object of culture-planning which was sought to promote westernization (125). In the same vein, Paker suggests that Cevdet's Hamlet plays a "stimulating if not revolutionary role in the intellectual reawakening of the Ottoman political and cultural milieu" (91).

Efforts at westernization were accelerated in 1923 following the proclamation of the Turkish Republic by Mustafa Kemal Atatürk and his reformers. As a result, the cultural and religious traditions of the Ottomans were being eliminated in order to encourage the Turkish citizenry to identify with Kemalist principles. ${ }^{7}$ Atatürk and his reformers placed a special mission on theatre in general, and to Hamlet, in particular. As And points out, Atatürk believed that theatre "should further state politics" (216). As a result, it was utilized as a form of "subterfuge to propagate" republican reforms (219) and, to use Tahir-Gürçağlar's words, to "transform the habitus of the people" (Politics and Poetics 59). In order to elicit a change in the Turkish people's dispositions, it was necessary to purge the Turkish language of vocabulary from Arabic and Persian origin. Even though the narrative of language purism, which constructs Turkish otherness in the face of the Arabic and Persian languages, dates back to the 1910s within the framework of the so-called "New Language" (plain language) movement (Tahir-Gürçağlar, Politics and Poetics 52), it was not until 1928 when the Arabic type script was replaced with a hybridized Latin alphabet in order for the Turkish citizenry to attain a higher level of literacy as well as familiarize the general public with western culture. As a result, the national theatre in the newly formed Turkish republic was conceived as "the purest and most aesthetic expression" of Turkish (And 224). Since Atatürk wished to disseminate pure Turkish words among the general population, he replaced Arabic and Persian words in the plays with his own suggestions (And 224).

\footnotetext{
7 Kemalism denotes a philosophy of modernization which directed the transformation of the multi-religious, multiethnic Ottoman Empire into the secular, unitary Turkish republic in line with Mustafa Kemal Atatürk's social, political, and economic reforms (for further reading, see Metin Heper's “Kemalism/Atatürkism”).
} 
In this context, the subsequent retranslations of Hamlet have been framed in line with the overarching grand narrative of Turkish nationalism. Hence, the discourse regarding several Hamlet retranslations have centred on the narrative of language purism in parallel with the language reform. For instance, Ayluçtarhan points to the ensuing need for a retranslation owing to Cevdet's "heavy style" imbued with Arabic and Persian words (66). Particularly noteworthy is the point that Cevdet's translation was ignored by the republican reformers (for a more detailed analysis of Cevdet's rendering, see Ayluçtarhan). Even though Cevdet acknowledged that his grandiloquent language caused inconvenience even for the educated readership (Cevdet, Shakespeare ve Hamlet 4323), and ultimately carried out a retranslation, the Ministry of Education went ahead with the publication of Kamuran Şerif Saru's translation in 1927.

Hamlet was retranslated in line with the requirements (e.g., fidelity to the source text's form and content as well as natural and fluent language use) of the Translation Bureau (1940-1966), which was established as a state-sponsored institution to carry out the translation of western classics in a systematic manner to achieve Turkish humanism, westernization, and cultural transformation. Given that Shakespeare's works were seen as a significant narrative source that would construct national culture and literature and that Shakespeare's use of political, historical, and mythical elements functioned as "an innovative model" for Turkish theatre (Paker 101), Hamlet was not only a source text that took up a place on the Translation Bureau's list, but it was also a text which would have a much more transformative impact on Turkish society as a whole. Therefore, Demirkol accentuates the narratives of "sacredness" and "immunity" associated with the Turkish translations of Hamlet and other Shakespearean works (45), reminding us that translations were expected to be loyal to Shakespeare's wording and style in the early republican era of Turkey.

The early-republican era versions of Hamlet were also framed within the official public narrative of secularism that emerged as a key principle of the new Turkish state. As Thomas Smith argues,

Turkish identity (Türkçülük) was defined in opposition to the rest of the Islamic world, and Turks remain cool toward pan-Islamic movements. The mechanics of nationbuilding - rehabilitating the 'Turk' (which had been a pejorative under Ottoman rule), closing the Caliphate, Turkifying the history of Anatolia, cleansing the Turkish language of Arabic and Persian words, adopting the Roman alphabet in place of Arabic script, banning the fez and other manifestations of 'the Orient' - distanced Turkey from the Arab world in particular (309).

In this context, Paker associates Muhsin Ertuğrul's Hamlet translation with his particular narrative vantage point that privileged secularism (25). By the same token, Howard points out that the Turkish people were acquainted with Hamlet within the framework of the Kemalist programme of "create[ing] a secular literature" (211). The ensuing translations carried out by Adivar and Turhan, Burian and Eyüboğlu have also been associated with the Kemalist objective of establishing a secular literary system (see Paker 94). In line with this point, Arslan frames Adivar and Turhan's translation within the framework of an ideologically charged narrative, arguing that their translation respected "the republican reform programmes by conforming to a 'pure' Turkish and also to humanistic ideas fostered by the government-supported Translation Bureau [...]" (160). In a similar vein, Muhsin Ertuğrul views Burian's retranslation as a linguistic update, promoting the narrative that the retranslations symbolize the unceasing advancement of the Turkish language towards purity (145). 
Howard argues that Hamlet "had particular point in Turkey because of its history of coups and the frequent failure of democracy" (214). By virtue of the broader public narrative of military coups which surface in various discourses regarding Turkish versions of Hamlet, the text attained a symbolic status as a historiographic work, contributing to the narration of military takeovers in the Turkish context. As background to the previous point just stated, it is significant to highlight the causational elements behind the coups that have taken place in Turkey.

After the single-party rule of the Republican People's Party founded by Atatürk in 1923, Turkey's multi-party regime began with the establishment of the Democrat Party, which came to power in 1950. The Democrat Party's sympathy towards religion and adoption of conservative policies (e.g., return of Islamic values, dismissal of several modernization reforms introduced by the Republican People's Party, and so forth) led to the amplification of religious practices and to the rise of the Islamic sects (Karpat 353). Furthermore, its attempt to pressure opposition, and in particular left-wing extremism, ultimately resulted in a serious rift between the left-wing and rightwing groups. In response to the growing social strife, anarchy, and economic unrest, the Turkish military, which was a vanguard of Kemalism, took over the nation's political power and subsequently toppled the Democrat Party government in 1960. The ensuing 1961 Constitution's tolerance for social democrat and liberal activities enabled leftist ideologies to find their place in Turkey's agenda (Ciddi 1), which led to the establishment of private publishing houses, "whose leftist orientations gave rise to a recontextualization of the social role of translation" (TahirGürçağlar, Tercüme Bürosu Nasıl Doğdu 11).

In 1965, a new government was set up by the Justice Party, which, as a successor of the Democrat Party, was again sympathetic towards Islamic values. However, due to currency devaluation and student movements which intensified the social unrest, the ruling party received the 1971 military memorandum. In order to restore order, a cabinet of technocrats was established as an interim government under the auspices of the country's military forces. In this context, Hamlet 70 was produced by Algan as part of the leftist discourse, which situates Hamlet on the larger narrative of the differences between the left and right-wing factions of 1970s Turkey. Savass Arslan's discourse regarding this issue serves to illustrate particular points which establish a link between Algan's version of Hamlet and the military interventions taking place in Turkey. Exploring how Algan modified Hamlet's immediate narrative into a leftist narrative of anti-imperialism, Arslan focuses on Algan's addition of a prologue that projected the original storyline onto Turkey's reallife setting. He also underlines that Algan's use of certain excerpts from Atatürk's address to the Turkish youth (e.g., "your first duty is to preserve and defend Turkish independence and the republic forever") presents a narrative that defends and rationalizes the actions of the leftist youth (Arslan 161). Analysing Algan's cumulative use of specific elements (e.g., certain parts of the Address that replace Hamlet's soliloquy) from the narrative world of the Turkish people, Arslan emphasizes that the Turkish version maintains "the anti-Islamist and secular overtones of Kemalism, which had long characterized translations of the play" (161).

Focus now is placed on reviewing the discourse related to the Turkish film version of Hamlet released in 1976, titled Lady Hamlet. It is important to note that the traditional Turkish theatre excluded women until the foundation of modern Turkey in 1923. Since Atatürk prioritized women's liberation, he required modern dramatists to, "include at least one major female role of great character and virtue in every work" (And 224). In line with this point, Tony Howard notes 
that Erksan's repositioning of Hamlet is in complete harmony with the Kemalist principles (211). Hence, Howard frames the Turkish version within the larger narrative of Turkey's modernization project. Likewise, Bilgin points out that Erksan's reframing of the play within "a feminist context" in a way which "decolonizes" women and defies "the male-centred readings of the play" constructs an image of modernity that challenges patriarchal values (Bilgin 68-70). However, Sayin argues that Erksan's version only responds to "the demands of the film market" (29). Sayin both rejects the argument that Lady Hamlet has feminist overtones and implies that the cinematographic adaptation was a form of the commodification of Hamlet, to use Grossman's word.

On the other hand, Bilgin, who deals with Lady Hamlet as a form of transcultural appropriation, embeds the rewriting within the narrative of "Easternization" given that Erksan injects culture-specific elements (e.g., folk tales) of the East into a work from the canon of western literature (69). Bilgin argues that Erksan deconstructs Hamlet, which she refers to as an act of defying the cultural authority of the canonized West (70). Her review reveals the difficulty in identifying the image of Turkey that oscillates between being simultaneously European and Asian. Hence, her comments disclose that such cultural hybridity signifies an ambivalent Turkish image in which the Occident and the Orient meet and in the end complement the other.

It was not only Bilgin, who underlines that Lady Hamlet builds upon an eastern identity (72) and, to use Hutcheon's word (150), “indigenizes" Turkey's western other. Sayın also notes that a western cultural icon has been "indigenized, hybridized and reconstructed by the resources of Eastern European or Middle Eastern and Islamic codes of Turkish culture" (35). A particular example that is featured in the film version is Hamlet's motivation for vengeance that is reframed in the narrative of blood vengeance which still endures as a social practice in some areas of eastern Turkey. ${ }^{8}$ This is why, as Arslan also argues (160), the film version deviates from the earlier renderings' inclination to observe the Kemalist project of modernization and westernization.

At this point, it is safe to assume that the extratextual comments collaborate within a more general narrative of moulding Turkey's imagination of itself as a country positioned between Europe and Asia, so as a result vacillating between the discourses of westernization and easternization. Within this context, Erksan's rewriting of Hamlet seems to fit the image of Turkey, which permanently reshapes its western self and western other within its own shifting sociopolitical contexts. In order to thoroughly consider Erksan's rewriting of Hamlet, Sayın produces a very productive discourse by drawing on Yuri Lotman, who underlines that "Hamlet is not just a play by Shakespeare, but it is also the memory of all those historical events which occurred outside the text but with which Shakespeare's text can evoke association" (18-19). Sayın associates Erksan's rewriting of Hamlet particularly with the stage of transformation (20) where "the imported texts are entirely dissolved in the receiving culture" which then begins to generate its own texts (Lotman 147). In this context, Hamlet can be seen both as a "meaning-generating mechanism", in the words of Lotman (9), and as "a condenser of cultural memory" that can retain "the memory of its previous contexts" (Lotman 18).

Before we proceed to Yücel's and Gezen's versions of Hamlet, it is significant to scrutinize Turkey's socio-political landscape which potentially served as background to them. A potentially

\footnotetext{
8 Blood vengeance is an old tradition that requires the male members of a family to kill any male member of another family that damaged the former's unity and peace.
} 
significant point to bear in mind is that the street clashes between the left-wing and right-wing factions that occurred in late 1970s Turkey were subsequently followed by the 1980 military coup of the country. The process of apoliticization which went along with the process of economic liberalization was a significant outcome of the coup. In 1983, the Motherland Party swept to power by receiving the support of the liberal, nationalist, and pro-Islamic circles. Although the government's integration of the Turkish economy into the global market led the country towards modernization (Bakan and Bırdışlı 372), conservative Islamic values became prevalent after the coup owing to the significant role attributed to Sunni Islam to achieve public morality and social order (Mecham 165), to eliminate leftist radicalism, and to impede the return of the ideological clashes and political violence of the 1970s.

Hence, Demirkol suggests that Yücel's reframing of Hamlet within a different temporal and spatial setting (e.g., Turkey's Ottoman past) provided him the freedom of criticism since he maintained a "secure distance" from the politics of his time (126). Given that the narrative of Turks as "apolitical consumers of global market" was then prevalent (Lüküslü 33), Yücel might have tried to seem disengaged from the current politics of the time. Demirkol argues that Yücel might have wished to refrain from breaching the counter-terrorism laws that came into force following the 1980 military coup (128-132). Yücel's Hamlet, which had a sort of alienating effect on modern Turkish readers due to its "Ottomanized style", to use Shissler's words (240), was composed as a counter-narrative contesting the dominant narratives of the time (Arslan 163); however, the excessive use of obsolete Ottoman cultural elements and repositioning of the characters in the Ottoman palace ran counter to the narrative positioning of previous translations that had strived to construct a modern image of Turkey compatible with Atatürk's visionary reforms. In relation to this point, Demirkol foregrounds the separation between the Orientalized Turkish image constructed by Yücel's translation and the image of modernity constructed by several previous translations. Furthermore, Arslan suggests that Yücel's version raised the eyebrows of the "Kemalist circles that hold that Western classics should not be so altered" (163). Yücel's version is identified in Arslan's review as being a "free or adaptational translation" that distorts "semantic fidelity" and "politicizes" a western piece, which went against the grain of the early republican norms set for translation (163).

Gezen's 1995 version Hamlet Efendi portrays the tension between Islamism and secularism in the context of popular culture. The play promotes significant Kemalist narratives (e.g., the significance of education for the youth) in order to display that the rewriter recreated Hamlet in line with the narrative position that had considerable currency in relation to the ideas of the early republican era in Turkey (162). At this point, the timing of Gezen's version also deserves notice; even though it was acknowledged that secularization was firmly established in Kemalist Turkey, the Islamist movement which followed the 1980 coup contested the fundamental principles of Kemalism by promoting Islamic identity in the social and public arena (Hemmati 58). This is why Arslan viewed Gezen's version as the "secularist and Kemalist rendering" of Hamlet that "reconfigured the secularist and Islamist opposition" (162).

Germane to the points just discussed is Çelenk's Hamlet Renkli Türkçe. In order to trace the motivation behind the construction of a link between Çelenk's version and the wider narrative of the Islamist-secular rift from various discourses, it is necessary to provide some background for Çelenk's rewriting. The 1999 Helsinki Summit's inclusion of Turkey in the European Union 
enlargement process turned Turkey's bid to westernization into a process of Europeanization. The Justice and Development Party, which came to power in 2002, committed itself to achieve the political reform process of the Copenhagen criteria and establish a European model of democracy through harmonization laws. However, despite its earlier pro-European and liberal-democratic stance, the ruling party has long been criticized for promulgating the conservative traditions of Turkey's Ottoman heritage and Islamic identity (Öniş 29). The party's claim for neo-ottomanism also added to the criticisms (Göçek 1-21). As a result, the secularist segments of the Turkish republic have tended to question the "party's loyalty to the founding principles of the Turkish Republic" (Çağlıyan-İçener 596).

In this respect, Çelenk's Hamlet Renkli Türkģe can be considered to have been framed through a variety of discourses as a narrative that indigenizes a western classic into the current Turkish political milieu in order to portray Islamism as a political movement that objects to a secular western identity. For example, Arslan focuses on how the Justice and Development Party government is portrayed as the Danish court in Çelenk's rewriting, and suggests that it idealizes "a contemporary, urban, intellectual strand of Kemalism," which champions Turkey's westward outlook against Islamism (164). Furthermore, Partovi Tazeh Kand foregrounds the creolizing role of Çelenk's rewriting (204), through the utilization of the concept of creolization in reference to "the appropriation of discourses or practices into a new context where they become naturalized" (Mooney and Evans 48). Kand notes that Çelenk's Hamlet creates a "mutual intermingling" by bringing together Turkish and western (anglophone) cultures (205), which marks the Justice and Development Party's representation of the Islamic cultural other both against the western world and against Turkey's secular establishment (Kand 113-115).

As for the Kurdish version, the play is framed on the basis of Kurds' vigorous reclaiming of cultural otherness and break from the Turkish identity, since it revives the old Kurdish tradition of dengbej (i.e. a melodious way of telling stories), which is complemented with traditional instruments such as the daf, davul (tupan), zurna (a woodwind instrument), and saz. The Kurdish songs, customs, and folkloric features that dominate the play from beginning to end provide an opportunity to foreground Kurdish culture and language. As a result, Kurdish Hamlet is framed within the narrative of a distinct Kurdish ethnic identity. For example, Bilgin focuses on the othering of Kurds in Turkish society (73), highlighting in the words of Sanders (19), that the Kurdish version presents a "revised point of view from the original, [...] voicing the silenced and marginalized".

At this point, one should note that Law No. 2932, which was put into place after the 1980 coup, interdicted both a separate Kurdish identity and a separate language (Kurdish) in Turkey. Therefore, according to Verstraete, the Kurdish version calls for "international visibility and awareness for Kurdish theatre and culture and its historical circumstance, particularly concerning the recognition of the Kurdish language in Turkey" (65). In the same vein, Bilgin argues that the Kurdish rewriting of Hamlet "calls for recognition of Kurdish culture and its own presence within the Western literary canon, signifying both Turkey and the rest of Europe" (71).

Verstraete also focuses on the rewriter's counter-discourse to the larger narrative that Kurdish is not poetic and hence not sufficient to reproduce a canonized western play (54). Therefore, it is safe to assume that the Kurdish version was conceived as a means of (re)imagining the Kurdish identity in order to contribute to the differentiation of Kurdish culture from its Turkish 
and western counterparts on both poetological and ideological grounds. The Kurdish rewriting of Hamlet further demonstrates that a western dramatic work can be reproduced in a Kurdish context (Bilgin 71) provided that Hamlet's mania with revenge is transformed into the eastern feud through the larger narrative of blood vengeance as circulated in some parts of eastern and south-eastern Turkey. Judging by these aforementioned points, it is reasonable to suggest that Tokgöz's version of Hamlet contests the canonization and sacredness of a western other by weaving a narrative dedicated to the idea of the eastern self.

Discourses regarding various versions of Hamlet reveal that the narratives elaborated through retranslations and post-translation rewritings of a work, and in this case a canonical western literary work, may ultimately shift alongside the ever changing socio-political atmosphere within a receiving culture such as Turkey. As viewed from the angle of the extratextual materials presented in this paper, what seems telling is that the Turkish image is ever torn between the dualities of modernity and tradition, secularism and religion, easternness and westernness, which ultimately not only stem from the country's historical roots, but also from its often amorphous geopolitical position.

\section{Concluding remarks}

This study set out to explore various discourses regarding the Turkish retranslations and posttranslation rewritings of Hamlet, and did so in an attempt to demonstrate how these individual discourses can circulate broader narratives that ultimately feed into the renegotiation of national self-image(s). It can be posited that reviews on the various versions of Hamlet in Turkish have in effect led to the construction of an image of Turkey, which is based solely on a dialectical opposition to a set of particular images and conceptions. Stated differently, almost all discourses regarding the Turkish renderings of Hamlet have been predicated upon the ontology of the idea of the other within the construction of Turkey's self-image. The creation and fostering of the idea of the other is a dynamic process, so a closer scrutiny of the related discourse has also foregrounded concepts of new others across a set of divergent lines (e.g., ideological, religious, ethnic, and so forth) in relation to changing political contexts which encompass the retranslations and rewritings of Hamlet.

It appears that the theme of cultural and social modernity has been the most frequently utilized narrative to position the earlier versions of Hamlet within the Turkish literary system. For example, the reviews of the retranslations and rewritings composed between 1927 and 1970 placed emphasis on how each broke free from the constraining ties associated with the country's Ottoman imperial heritage. They accentuate the narrative of Kemalism to frame the Hamlet versions within the context of Turkey's historical secular-Islamist divide. In addition, western identity has long been projected in opposition to the eastern other, that is to say, in opposition to the Islamic Orient. These reviews have also foregrounded the translators' and rewriters' efforts at constructing, strengthening, and disseminating the so to speak western identity through their renderings of Hamlet. Also, the terms of Turkification and Turkifying, which have been used interchangeably in most of these reviews, have been the most frequently circulated frames of reference to identify the translational practices given that transfer of western attributes onto the self were inevitable within the process of westernization of a nation which was not western. As a result, as Arslan suggests, new forms of Turkification can be observed in each retranslation and rewriting, notwithstanding its assertion of faithfulness to the source text (166). 
Several reviews relating to Turkish versions of Hamlet, for example, the 1927, 1941, 1944, and 1965 versions, directly focused on the narrative of language purism. In this context, it has been pointed out that the language of Hamlet has become purer in each successive retranslation and posttranslation rewriting. However, it is important to briefly point out that the 1992 version is an exception because it is permeated with several Ottoman words. On the one hand, the 1992 version was framed as promoting the Kemalist narrative of secularism, yet it is argued that the inclusion of Ottoman references as well as allusions to the Ottoman era are neither congruous with the official narrative of Kemalism nor rest squarely within the narrative position to which its rewriter was presumed to have subscribed.

Next, discourses regarding the 1976, 1992, 2004 and 2012 versions of Turkish Hamlet took on a narrative position considerably different from the others. In a sense, these versions were considered to have essentially reread Hamlet, once a trope of modernization, and instead offered an eastern-oriented alternative Turkish image associated with Turkey's eastern self. For example, the reviews presented antiquated yet still surviving eastern traditions such as blood vengeance in the 1976 version, the image of the Ottoman palace in the 1992 version, and Islamic references in the 2004 version which ultimately perpetuated the Orientalist image of Turkey. Furthermore, the 2012 version has become what is considered a full-fledged Kurdish rewriting of a Shakespearean text and in the process ostensibly disputes the western text's canonical status. The 2012 rewriting has also been viewed as a challenge to the Turkish canon of literature since the Turkish other has become a steady point of reference within various conceptions of Kurdish identity.

This research has not yielded any extratextual comment regarding the other retranslations (e.g., two retranslations published in 2012, one in 2013, one in 2014, two in 2017, one in 2018, and one in 2019). The close temporal proximity of these retranslations implies that Hamlet's status as a classic has called for successive retranslations given that canonicity and retranslation often go hand in hand. Some of these retranslations may be commercially-motivated because representing a canonical play as a result of its canonicity guarantee some market demand and it is, in the words of Venuti, "cheaper to publish than copyrighted texts, which require the purchase of translation rights from the source-text author or his assignees" (100).

This study has ultimately revealed that the way Hamlet has been both re-membered and dismembered throughout the Turkish literary landscape in line with the narratives that accompany it influenced the nation's image of itself. As evidenced through this analysis, extratextual discourses have dealt with the Turkish versions of Hamlet within the framework of three prominent sociopolitical issues: (i) westernization that later evolved into Europeanization within the Turkish context, (ii) secularism, and (iii) nationalism (e.g., Turkish versus Kurdish identity) which have remained at the forefront of Turkey's cultural, political, and social agenda from the onset of the Turkish republic.

Finally, it appears that Gentzler's elaboration in relation to post-translation rewriting, which illuminates how texts circulate, "not just source to target" but instead "to target and beyond", and from "texts to images" (112), has been very productive for the present study's attempt at researching beyond retranslation in order to more comprehensively unpack Hamlets posttranslation reverberations as they occur within the Turkish cultural milieu. The variety of Turkish versions reviewed in this study revealed that a majority of Hamlet was in effect translated into images, for example, dress (e.g., Hamlet in a parka and combat boots in the 1970 version), sound 
(e.g., a famous classical Turkish song "Makber", meaning grave, in the 1972 version), setting (e.g., the Ottoman palace in the 1992 version), and dance (e.g., Anatolian and Middle Eastern folkloric dance in the 2012 version) have contributed to much of the work's meaning within the Turkish context. In the end, those images in turn play an extremely important role in the imagining of the collective Turkish identity over a variety of time periods. Therefore, closer scrutiny of the various extratextual discourses in relation to the Turkish post-translation rewritings of Hamlet can be seen as justifying Gentzler's contention that "more than the influence of the translated text, it is the influence of the images of that text upon the stage or in the film that enhances reception" (217). 


\section{REFERENCES}

And, Metin. "Atatürk and the Arts with Special Reference to Music and Theater," Atatürk and the Modernization of Turkey, edited by Jacob M. Landau, Westview Press, 1984.

Arslan, Savaş. "Turkish Hamlets". Shakespeare (1745-0918) (1745-0918) 4.2, 2008, pp.170-182.

Ayluçtarhan, Sevda. "Dr. Abdullah Cevdet's Translations (1908-1910): The Making of a Westernist and Materialist 'Culture Repertoire' in a 'Resistant' Ottoman Context." M.A. thesis, Boğaziçi, 2007.

Bakan, Selahaddin and Fikret Bırdışlı. "The Analysis of Nationalism, Statism, State Nationalism and State Economy in Turkey's Modernisation Process". Süleyman Demirel University Journal of Faculty of Economics and Administrative Sciences, 15(1), 2010. 357-376.

Baker, Mona. Translation and Conflict: A Narrative Account, Routledge, 2006.

Bassnett, Susan and André Lefevere, eds. Translation, History and Culture, Pinter, 1990.

Baudrillard, Jean. The Illusion of the End, translated by Chris Turner, Stanford University Press, 1994.

Beller, Manfred. "Perception, Image, Imagology". Imagology: The Cultural Construction and Literary Representation of National Characters, edited by Manfred Beller, and Joep Leerssen. Rodopi, 2007, pp. 3-16.

Berk-Albachten, Özlem "Translating the "West": The Position of Translated Western Literature within the Turkish Literary Polysystem”, RiLUnE, n. 4, 2006, pp. 1-18.

Bilgin, Inci. "Hamlet in Contemporary Turkey: Towards Postcolonial Feminist Rewrites?", Multicultural Shakespeare: Translation, Appropriation and Performance, vol. 12 (27).

Bozkurt, Bülent "Hamlet’i Türkçe'ye Çevirirken". Hamlet, translated by Bülent Bozkurt, Remzi, 1999, pp.17-21.

. "Shakespeare'in Bütün Sözcükleri”. Akşsamllk (18 Nisan 2003) (Akşam Gą̧etesìnin kitap eki), 2003, 4-5.

Cevdet, Abdullah. "Shakespeare ve Hamlet'. İctihad, n. 226, 1927, pp.4319-4323. "Hamlet in Tahlili." İctihad, n. 309, 1930, pp.5509-5511.

Çağllyan-İçener, Zeyneb. "The Justice and Development Party's Conception of "Conservative Democracy”: Invention or Reinterpretation?” Turkish Studies, 10:4, 2009, pp. 595-612.

Çelenk, Semih. Hamlet Renkli Türkşe [Hamlet in Colour in Turkish]. İzmir, 2004.

Ciddi, Sinan. Kemalism in Turkish Politics: The Republican People's Party, Secularism, and Nationalism, Routledge. 2009.

Demirkol, Neslihan. "Can Yücel'in Shakespeare Çevirilerinde 'Sadakat' [Loyalty in Can Yücel's Translations from Shakespeare]”, MA thesis, Bilkent Üniversitesi, Ankara, 2006.

Enginün, İnci. Tanzimat Devrinde Shakespeare Tercümeleri ve Tesiri, Istanbul Universitesi Yayinlari, 1979.

Ertuğrul, Muhsin. Gerçeklerin Düsleri: Tiyatro Düşünceleri [Dreams of Realities: Thoughts on Theatre], Dr. Nejat F. Eczacıbaşı Vakfi, 1993.

Erksan, Metin. Intikam Meleği, Ugur Film, Turkey,1976.

Eyüboğlu, Sebahattin. Çevirenin Sözü. Hamlet, translated by Sebahattin Eyüboğlu, İstanbul: Remzi Kitabevi, 1965, p.3.

Fludernik, Monika. Introduction to Narratology, Routledge, 2009.

Genette, Gérard. Paratexts: Thresholds of Interpretation, translated by Jane E. Lewin. Cambridge University Press, 1997.

Gentzler, Edwin. Translation and Rewriting in the Age of Post-Translation Studies, Routledge, 2017. 
Gezen, Müjdat. Hamlet Efendi ve Istanbul Mürikali ["Hamlet Efendi” and the Istanbul Musical], Mitos Boyut, 1995.

Göçek, Fatma Müge. The Transformation of Turkey: Redefining State and Society from the Ottoman Empire to the Modern Era, I.B. Tauris, 2011.

Grossman, Kathryn M. “Classic to Pop Icon: Popularizing Hugo.” The French Review 74.3, 2001, pp. 482-495.

Hemmati, Khash. "Turkey Post 1980 Coup D'etat: The Rise, the Fall, and the Emergence of Political Islam.” Illumine 12, no. 1, 2013, pp. 58-73.

Heper, Metin. "Kemalism/Atatürkism”, The Routledge Handbook of Modern Turkey, edited by Heper, M. and S. Sayar1, Routledge. 2012. pp.139-148.

Howard, Tony. Women as Hamlet: Performance and Interpretation, Cambridge University Press, 2007.

Hutcheon, Linda. A Theory of Adaptation, Routledge, 2006.

Kand, Partovi Tazeh Parviz. Adaptations of Hamlet in Different Cultural Contexts: Globalisation, Modernism and Post-modernism, doctoral thesis, University of Huddersfield, 2013.

Karpat, Kemal. 'Political Developments in Turkey, 1950-70', Middle Eastern Studies, Vol. 8, No. 3, 1972, pp. 349-375.

Leerssen Joep. "Imagology: History and Method", Imagology: The Cultural Construction and Literary Representation of National Characters. A Critical Survey, edited by M. Beller and J. Leerssen, Rodopi, 2007, pp. 17-32.

Lotman, Yuri. Universe of the Mind: A Semiotic Theory of Culture, translated by. A. Shukman, intro. U. Eco, I.B. Tauris, 1990.

Lüküslü, Demet. "Constructors and Constructed: Youth as a Political Actor in Modernising Turkey", Revisiting Youth Political Participation: Challenges for Research and Democratic Practice in Europe, edited by Joerg Forbrig, Council of Europe Publishers, 2005, pp. 29-35.

Mecham, Quinn. Institutional Origins of Islamist Political Mobilization, Cambridge University Press, 2017.

Mehmed Nâdir. "nâmı şöhretgîr-i âfâk olan «şekspir» in tercüme etdiğim bazı âsârı içinden birkaç söz toplayub (hazine-i evrak) a derc buyurulmak üzere irsâl eyledim... imza nâdir", Hazine-i Evrak, No. 39, 1298, pp. 617-20.

Mooney, Annabelle and Betsy Evans. Globalisation: The Key Concepts, Routledge, 2007.

Nergaard, Siri and Stephano Arduini. "Translation: A New Paradigm", Translation: A Transdisciplinary Journal, Inaugural Issue: 8- 17, 2011.

Okulska, Inez. "From Intersemiotic Translation to Tie-in Products." Forum of Poetics, Fall, 2016, pp.58-69.

Öniş, Ziya. "Conservative Globalism at the Crossroads: The Justice and Development Party and the Thorny Path to Democratic Consolidation in Turkey", Mediterranean Politics, 14(1), 2009, $21-40$

Özgüven, Fatih. “Türkçe Söyleyen: Can Yücel”. Radikal İki, 5 Eylül 1999, p. 8.

Paker, Saliha. 'Hamlet in Turkey', New Comparison, 2: Autumn, 1986, pp. 89-108.

Pym, Anthony. Method in Translation History, St. Jerome Publishing. 1998.

Samoyault, Tiphaine. "Retraduire Joyce". La retraduction, edited by Robert Kahn, and Catriona Seth, Publications des Universités de Rouen et du Havre, 2010, pp. 231-240.

Sanders, Julie. Adaptation and Appropriation, Routledge, 2006. 
Sayın, Gülşen. "Shakespeare in Turkish Cinema: A Cultural Transfer from Hamlet to The Angel of Vengeance (1976)", Journal of Adaptation in Film \& Performance, 4: 1, 2011, pp. 17-37.

Shakespeare, William. Hamlet, translated by Abdullah Cevdet, Kütüphane-i İçtihad, 1908.

—. Hamlet, translated by Muhsin Ertugrul, İstanbul City Theatre, 1927.

. Danimarka Prensi Hamlet (Hamlet, Prince of Denmark) translated by Kamuran Şerif, Devlet Matbaas1, 1927.

—. Danimarka Prensi Hamlet (Hamlet, Prince of Denmark), translated by Halide Edib Adivar and V. Turhan, İstanbul Üniversitesi Edebiyat Fakültesi Neşriyatı, 1941.

- Hamlet, translated by Orhan Burian, Maarif Matbaas1, 1944.

- Hamlet, translated by Selahaddin Eyüboğlu, Remzi Kitabevi, 1965.

- Hamlet, Barnes \& Noble Books, 1992.

- Hamlet, translated by Can Yücel, Adam Yayınları, 1992.

- Hamlet, translated by T. Sağlam, Timaş Yayınları,1999.

. Hamlet, translated by Bülent Bozkurt, Remzi, 1999.

- Hamlet, translated by Esen Genç, Ve Edebiyat Yayınları, 2002.

. Hamlet, translated by Orhan Akıc1, Beda Yayınları, 2004.

- Hamlet, translated by Doğan Can, Mitos Boyut, 2012.

- Hamlet, translated by Vedii İlmen, Yaba, 2013.

. Hamlet, translated by Özdemir Nutku, Mitos Boyut, 2013.

. Hamlet, translated by Yeşim Misırcı, Paraf Yayınları, 2014.

Hamlet, translated by Ahmet Gözler, Artı Ofset, 2017.

. Hamlet, translated by Halit Erdem Oksaçan, Düzyazı Yayınevi, 2017.

- Hamlet, translated by Dilek Topal, Demeter Yayınları, 2017.

Hamlet Danimark a Prensi, translated by Seçil Akın, Gece Kitaplı̆̆1, 2019.

Shissler, Holly. Between Two Empires: Ahmet Ağağglu and the New Turkey, I. B. Tauris, 2003.

Smith, Thomas W. "Between Allah and Atatürk: Liberal Islam in Turkey", The International Journal of Human Rights, 9:3, 2005, pp. 307-325.

Somers, Margaret R. and Gloria D. Gibson. "Reclaiming the Epistemological "Other": Narrative and the Social Constitution of Identity", Social Theory and the Politics of Identity, edited by Craig Calhoun, Blackwell, 1994, pp. 37-99.

Şengel, Deniz. "Shakespeare'den Türkçe'ye İlk Çeviri (1881): Mehmed Nadir ve Hamlet'ten 3 Pasaj", Afyon Kocatepe Üniversitesi Sosyal Bilimler Dergisi, X, 1, 2008, pp. 1-18.

Tahir-Gürçaglar, Şehnaz. "Tercüme Bürosu nasıl doğdu? Birinci Türk Neşriyat Kongresi ve Çeviri Planlamas1 (How was the Translation Bureau Born? The first Turkish Publishing Congress and Translation Planning)" Ceviri Seçkisi I/ Çeviriyi Düsünenler (An Anthology of Translation/ Thinkers of Translation), edited by M. Rifat, Sel, 2008a, pp. 37-43

- The Politics and Poetics of Translation in Turkey, 1923-1960, Rodopi, 2008b.

Tarif, Julie. "(Re)Translating as Re-membering", TranscUlturAl: A Journal of Translation and Cultural Studies, vol. 8.1, 2016, pp.38-56.

Toksöz, Celil. Hamlet (in Kurdish). Diyarbakır Devlet Tiyatrosu Stage Production, 2011.

Uluşahin, Aslı. "Hamlet’in Türkçedeki ilk sansürsüz çevirisi, ilk kez Türkiye'de yayımlanıyor (The first Uncensored Turkish translation of Hamlet is to be published for the first time in Turkey)." Kültür Servisi, 13 June 2017, https://www.kulturservisi.com/p/hamletinturkcedeki-ilk-sansursuz-cevirisi-ilk-kez-turkiyede-yayimlaniyor/ 
TranscUlturAl, vol. 12.1 (2020), 120-139.

http://ejournals.library.ualberta.ca/index.php/TC

Venuti, Lawrence. Translation Changes Everything: Theory and Practice, Routledge, 2013.

Verstraete, Pieter. “'Acting' under Turkey's State of Emergency”, Performance Matters, 4.3, 2018, pp.49-75. 